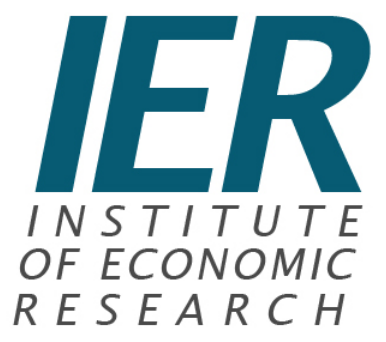

Institute of Economic Research Working Papers

No. $53 / 2017$

\title{
The Most Valuable Global Brands and Condition of Economies: a Spatial Approach
}

\section{Wioleta Kucharska, Karol Flisikowski}

Article prepared and submitted for:

$9^{\text {th }}$ International Conference on Applied Economics Contemporary Issues in Economy, Institute of Economic Research, Polish Economic Society Branch in Toruń, Faculty of Economic Sciences and Management, Nicolaus Copernicus University, Toruń, Poland, 22-23 June 2017

Toruń, Poland 2017

(C) Copyright: Creative Commons Attribution 3.0 License 


\author{
Wioleta Kucharska \\ Karol Flisikowski \\ Wioleta.Kucharska@zie.pg.gda.pl \\ Karol.Flisikowski@zie.pg.gda.pl \\ Gdansk University of Technology, Gdańsk, Poland
}

\title{
The Most Valuable Global Brands and Condition of Economies: a Spatial Approach
}

\author{
JEL Classification: F63, M31
}

Keywords: GDP; brand value; spatial economics

\begin{abstract}
Research background: Brands are considered to be the most valuable asset of a company. Some of them achieve spectacular global results. The significance of global brands is proved by the fact that their value is often greater than the sum of all company's net assets.

Purpose of the article: The aim of this article is to highlight that brand value does not only create company's value but also leverages economies. We claim that even though global brands are sold worldwide they more strongly contribute to the development of economies in the countries where these brands' owners are located.

Methodology/methods: Based on 500 Brandirectory, the most Valuable Global Brands ranking powered by Brand Finance, we have discovered a spatial-economic autocorrelation to illustrate the potential interdependency between GDP and brand value which constitutes a foundation for further construction of a spatial regression model. Because the ranking data was only available for the year 2014, the analyses were performed for 33 selected countries.

Findings: Our findings confirm the hypothesis that assumptive spatial dependencies matter for the investigated relationship between brand value and GDP. The evidence is based on the spatial error and the spatial lag model, although the former has a slightly better performance than the latter alternative.
\end{abstract}

\section{Introduction}

Brands are considered to be the most valuable asset of a company (Kamakura \& Russel, 1993, pp. 9-22; Barwise et al., 1990, pp. 43-59). Some of these brands achieve spectacular global results. Referring to the 500 Brandirectory 2016, the most Valuable Global Brands ranking powered by Brand Finance, ex. the value of No 1: Apple, is: $\$ 145,918 \mathrm{~m}$. The significance of global brands is proved by the fact that their value is often greater 
than the sum of all the company's net assets (Barwise et al., 1989, pp. 34). The meaning of brands for businesses, companies, and corporations is evident (Zéghal \& Maaloul, 2011, pp. 262-274; Belo, Lin \&Vitorino, 2014, pp. 150-169). Therefore, the research question is: do global brands only create company's value or also leverage countries' economies?

The knowledge-based 'network economy' has contributed greatly to economic growth in recent years (Malik, Ali \& Khalid, 2014, pp. 32-48). According to Nakamura (2010, pp. 135-155), intangible investment expenditures have risen from roughly $4 \%$ of U.S. GDP in 1977 to $9-10 \%$ in 2006. Referring to World Bank estimates (Hamilton, et al., 2005, pp. 6170 ), approximately $78 \%$ of the world's wealth is attributed to intangible capital. In developing nations, intangible capital accounts for $59 \%$ of the wealth, while in OECD countries this share is approximately $80 \%$. Intangible capital is an important argument of a nation's wealth. The 'new economy' is underpinned by intangible capital (De, 2014, pp. 25-42) such as brands. Brand builders are the new primary producers in our so-called knowledge economy' (Klein, 2000, pp.196). Thus, we have decided to examine how global brands contribute to the development of economies of the countries where these brands' headquarters are located. We are going to start with the current literature review looking for the answer.

Only a few scientific articles correspond with our research question. Perhaps the reason is that the answer requires multidisciplinary research at the intersection of Management, Marketing, Economics and Statistics. Referring to Pike (2009, pp. 190-213; 2013, pp. 317-339) the conclusion about brands and branding geographies is that they have the potential to stimulate a novel approach to addressing spatial questions at the intersections of economic, social, cultural, political and ecological geographies. Particularly, referring to Pike (2015, pp. 40-53), one of the most important approaches of branding geographies is spatial circuits of brand value and meaning and uneven development. Referring to this field, one of the most interesting papers was written by Ferilli, et al. (2016, pp. 62-75) who examined the correlation between the Top 100 Most Valuable Global Brands positioning and positioning of the corresponding countries in terms of quality perceptions. Their findings suggest that although the correlation between positioning of a country and positioning of corporate brands exists, it strongly depends on particular categories and economy sectors which present different levels of representativeness of the country's most typical attributes. Although the presented results display a strong connection between the most valuable brands and their countries of origin, there is no evidence supporting the existence of a connection between brand value and a particular country's economic condition. Thus, we have decided to examine how global brands contribute to the development of economies. Referring to 
Wang, et al., (2015, pp. 93-102) Gross Domestic Product per capita (GDPpc) is widely accepted among several social-economic indicators as the most efficient indicator of per capita economic condition. This is why we have decided to choose the GDPpc as an indicator of the economy's condition. To our knowledge, our paper is the first study that examines the potential interdependency between brand values and GDPpc of the countries where these brands' headquarters are located. Next, it will constitute a foundation for construction of a spatial regression model.

\section{Method of the research}

The empirical analysis was performed in a few stages. In the first of them we made a preliminary assessment of statistical significance of the relationship and spatial autocorrelation for brand values, which constituted the basis for selecting the final form of regression model. Next, we estimated coefficients of the most appropriate form of spatial regression model. The brand value data was accepted on the basis of the yearly published ranking of brand value Branddirectory 500 top global brands 2014 ranking powered by Brand Finance (Brandirectory, 2014). The analyses were performed for 33 selected countries, which are not in every case reciprocal neighbours. Thus, it was necessary to construct a spatial weights matrix based on economic distances (Pietrzak, 2010, pp. 79-98). The value of real GDP (2014) was chosen for that measure. This kind of technical nests inside the spatial model an additional interpretation of coefficients.

In ordinary least squares (OLS) regression it is assumed that the modeled phenomena or processes are independent of their location, so there is no interaction between the two objects. This assumption is not always suited to the analysis of socio-economic phenomena in spatial terms. According to the so-called. the first law of geography formulated by Tobler (1970, pp. 234-240) all objects in space (observation units) interact, and spatial interactions are the greater, the smaller the distance between objects. Thus, in the analysis and modeling of data located we must take into account the spatial interactions, which may relate to both the dependent variable and the random component. In a situation where the value of the dependent variable in a given location affect the value of this variable from other locations, there is the so-called spatial autoregression.

The basis for the selection of the most accurate form of the regression model is the analysis of spatial autocorrelation. It is defined as ,the degree of correlation of observed values of the variable at his different locations" (Suchecki \& Olejnik, 2010, pp. 103). This means that the value of the modeled variable is related to values of the same variable in other locations, and the degree of relationship in accordance with Tobler's rule (closer objects are more relevant than distant) affect the relative position of objects and 
their geographical (or economic) distance. Specification of that matrix belongs to arbitrary decisions taken by a researcher and a choice of the alternative method of weighing is often due to the knowledge of the spatial structure of the phenomenon and links between units (Kossowski, 2010, pp. 9-26; Łaszkiewicz, 2014a, pp. 145-168). Spatial weights matrix is a structure whose elements we take the value 0 when the two objects $i, j$ are not neighbors, and 1 otherwise.

Specification of spatial weight matrices is a prerequisite and the first step in the analysis of spatial autocorrelation. Among many measures used for spatial relationships testing the most commonly used is Moran's I statistic (Longley et al. 2005, pp. 86-107).

In this paper we proposed two basic models with spatial effects, although it should be mentioned, that these are only the most popular examples of the wide range of spatial models reported in the literature multiplied with their numerous extensions and modifications. Spatial regression models like SAR - spatial autoregressive models (also classified as spatial lag models - SLM) or spatial error models (SEM) are used in case of spatial autocorrelation (Rogerson, 2001, pp. 215-227; Kossowski, 2010, pp. 9-26).

\section{Results}

In the first stage of the analysis, the calculations of spatial autocorrelation Moran's measure for Brand Value were performed. When spatial autocorrelation statistics are computed for variables, such as GDP or Brand value, they are based on the assumption of constant variance. This is usually violated when the variables are for areas with greatly different populations. That is why we should implement here the Assuncao-Reis empirical Bayes standardization to correct it (Assunção \& Reis, 1999, pp. 21472162). Both results are shown in Table 1.

Table 1. Spatial autocorrelation statistic for Brand Value.

\begin{tabular}{|l|l|l|l|l|l|}
\hline $\begin{array}{l}\text { Spatial autocorrelation } \\
\text { type }\end{array}$ & Moran's I & $\mathrm{E}(\mathrm{I})$ & $\sqrt{\operatorname{Var}(I)}$ & $\mathrm{Z}_{\mathrm{I}}$ & $\mathrm{p}$-value \\
\hline Univariate & 0.1766 & -0.0312 & 0.0329 & 6.3229 & 0.0070 \\
\hline $\begin{array}{l}\text { Univariate with empiri- } \\
\text { cal Bayes standardiza- } \\
\text { tion }\end{array}$ & -0.1790 & -0.0311 & 0.0565 & -2.6176 & 0.0044 \\
\hline
\end{tabular}

Source: Own calculations performed in GeoDa.

As shown in Table 1., the bayesian correction of the Moran's I measure of autocorrelation for brand values through the differences in scale of the GDP makes this statistic more accurate here and completely changes its character. Negative, statistically significant $(\mathrm{p}<0.01)$ spatial autocorrelation of the 
brand value is the basis to make the estimation of the structural parameters of spatial regression models in the next step of our analysis (Rogerson, 2001, pp. 215-227; Kossowski, 2010, pp. 9-26). In Table 2. the results of an estimation of linear regression models LM and regression models based on the matrix of spatial weights: SEM (spatial error model) and SLM (spatial lagged model) are presented.

Table 2. Estimation of linear and spatial regression functions for GDP (p-values in brackets).

\begin{tabular}{|l|l|l|l|}
\hline Model & LM & SEM & SLM \\
\hline constant & $\begin{array}{l}1.29283 \mathrm{e}+06 \\
(0.001662)\end{array}$ & $394368(0.00162)$ & $173531(0.32311)$ \\
\hline Brand value & $\begin{array}{l}8822.05 \\
(0.000000)\end{array}$ & $14944.9(0.00000)$ & $670.502(0.13136)$ \\
\hline$\square / \square$ & & $-0.939922(0.00000)$ & $0.937984(0.000000)$ \\
\hline $\mathrm{R}^{2}$ & 0.55005 & 0.902002 & 0.960771 \\
\hline Log-likelihood & -534.824 & -512.389 & -498.84 \\
\hline Akaike criterion & 1073.65 & 1028.78 & 1003.68 \\
\hline
\end{tabular}

Source: Own calculations performed in GeoDa / R.

The obtained results (presented in Table 2.) have correct statistical properties (LR and BP tests, significance of coefficients, Akaike criterion, R2) and the correct economic interpretation only for LM and SEM models. The spatial lag model (SLM) showed no statistical significance of parameters and wrong (apparently poorly resistant to differences in the scale of the modeled variable) positive sign of $\square$. Spatial error model (SEM) however, proved us the highest $(96 \%)$ determination coefficient and high $(\mathrm{p}<0,01)$ statistical significance. The use of spatio-economic weight matrices gave us a very good fit of the model to the empirical data, which can be seen in the values of the logarithm of the likelihood function, values of the coefficient of determination and also Akaike criterion. The presented fit to the empirical data is mainly due to more complete description of the spatial autocorrelation of brand value. The choice of the final form of the regression model (SEM) caused a further significant improvement of explanatory abilities of the analysis.

\section{Discussion and Limitations}

The results presented above corroborate the assumption made in the introduction regarding the relationship between best global brands and the condition of economies where brand owners are located. It may seem dis- 
putable however to what extent it is justifiable to analyze the influence of global brands on economies of countries where these brand owners' headquarters are located if we take into account their global reach. Thus, bearing in mind the fact that global brands are one of the most valuable assets of "global factories" and when global companies invest in brands (Buckeley, 2009, pp. 6) they perform constant spatial reorganisation, internationalization and integration of all processes connected with brand value creation which make it difficult to assign them to the one separate country. There is no question about globality of these processes. The question can be asked why the decision about examining the problem of spatial dependencies for the investigated relationship between brand value and GDP of the country where the brand owner's headquarters is located. Referring to Buckeley (2009, pp. 131-143), we claim that although "global factories" put a radical shift into generally all economies of all the locations of all their activities, the control or orchestration of these operations remains very firmly within the advanced countries (Buckley \& Strange, 2015, pp. 237249), where the headquarters of the owners of "global factories" are located.

Moreover, bearing in mind the presented results of our research, it is worth highlighting that the whole set of 500 cases of global brands' value data has been assigned to only 33 countries, whereof $38 \%$ of them to the US and 33\% to the Europe. None of the European brands was assigned to the old ex Eastern Bloc. Taking into consideration all the above, let us summarize: global brands and economies are strongly related.

\section{Conclusions and Implications}

The spatial autocorrelation analysis of this paper confirms a positive association between the GDPpc of the country where the brand owner's headquarters is located and the brand value, as was emphasized in the introduction. The presented results lead to the conclusion that global brands can strongly leverage economies. However, in our study we did not compare global brands' influence on other drivers of countries' economies. It would be interesting to examine, and compare results of, the relationship of brand value with other economic indicators referring to the condition of economies. Correlation analysis of the dynamics in time of this relationship could also result in reaching a thought-provoking conclusion. The presented findings prove that having strong global brands is positive for economies thus governments should create favorable conditions for the development of global brands. It not only leverages economies but, referring to Ferilli et al. (2016, pp. 62-75), builds a positive image of the country where the brand

originates. 


\section{References}

Anselin, L. (1988). Lagrange multiplier test diagnostics for spatial dependence and spatial heterogeneity. Geographical analysis, 20(1). DOI: https://doi.org/10.1111/j.1538-4632.1988.tb00159.x

Assunção, R.M., \& Reis, E.A. (1999). A new proposal to adjust Moran's I for population density. Statist. Med., 18. DOI: http://dx.doi.org/10.1002/(SICI)10970258(19990830)18:16<2147::AID-SIM179>3.0.CO;2-I

Barwise, P., Higson, C., Likierman, A., \& Marsh, P. (1989). Accounting for brands. London: London Business School and The Institute of Chartered Accountants in England and Wales.

Barwise, P., Higson, C., Likierman, A., \& Marsh P. (1990). Brands as Separable Assets. Business Strategy Review, 1(2). DOI: https://doi.org/10.1111/j.14678616.1990.tb00010.x

BBC, (2014). http://www.bbc.com/news/technology-29833131(03.01.2017)

Belo, F., Lin, X., \& Vitorino, M. A. (2014). Brand capital and firm value. Review of Economic Dynamics, 17(1). DOI: http://dx.doi.org/10.1016/j.red.2013.05.001

Buckley, P.J (2009). The impact of the global factory on economic development. Journal of World Business, 44(2). DOI: http://dx.doi.org/10.1016/j.jwb.2008.05.003

Buckley, P.J., \& Strange, R. (2015). The governance of the global factory: location and control of world economic activity. Academy of Management Perspectives, 29(2). DOI: http://dx.doi.org/10.5465/amp.2013.0113

Brandirectory (2014). The most 500 Valuable Global Brands Ranking, Brand Finance http://brandirectory.com/ (03.01.2017)

De, S. (2014). Intangible capital and growth in the 'new economy': Implications of a multi-sector endogenous growth model. Structural Change and Economic Dynamics, 28. DOI: http://dx.doi.org/10.1016/j.strueco.2013.11.003

Ferilli, G., Sacco, P. L., Teti, E., \& Buscema, M. (2016). Top corporate brands and the global structure of country brand positioning: An AutoCM ANN approach. Expert Systems with Applications, 66. DOI: http://dx.doi.org/10.1016/j.eswa.2016.08.054

Hamilton, K., Ruta, G., Bolt, K., Markandya, A., Pedroso-Galinato, S., Silva, P., Ordoubadi, M. S., Lange, G.M., \& Tajibaeva, L. (2005). Where is the wealth of nations?: measuring capital for the 21st century. The World Bank, Washington DC.

Kamakura, W. A., \& Russell, G. J. (1993). Measuring brand value with scanner data. International Journal of Research in Marketing, 10(1). DOI: http://dx.doi.org/10.1016/0167-8116(93)90030-3

Klein, N. (2000). No logo. London: Flamingo.

Kopczewska, K., 2010, Modele zmian stopy bezrobocia w ujęciu przestrzennym, Wiadomości Statystyczne, 5.

Kossowski, T., (2010), Teoretyczne aspekty modelowania przestrzennego w badaniach regionalnych, Biuletyn Instytutu Geografii Spoteczno-Ekonomicznej i Gospodarki Przestrzennej Uniwersytetu im. Adama Mickiewicza, Seria Rozwój Regionalny i Polityka Regionalna, 12. 
Longley, P. A., M. F. Goodchild, D. J. Maquire, \& D.W. Rhind (2005). Geographic Information Systems and Science, second edition, New York: Wiley.

Ludwiczak, B., (1991), Korelacja przestrzenna, A. Zeliaś (red.), Ekonometria przestrzenna, Państwowe Wydawnictwo Ekonomiczne, Warszawa.

Łaszkiewicz, E., (2014a), Operacjonalizacja zależności przestrzennych $w$ postaci macierzy wag, J. Suchecka (red.), Statystyka przestrzenna. Metody analiz struktur przestrzennych, Wydawnictwo C.H. Beck, Warszawa,

Łaszkiewicz, E., (2014b), Przegląd macierzy wag przestrzennych, J. Suchecka (red.), Statystyka przestrzenna. Metody analiz struktur przestrzennych, Wydawnictwo C.H. Beck, Warszawa.

Malik, K. Z., Ali, S. Z., \& Khalid, A. M. (2014). Intangible capital in a real business cycle model. Economic Modelling, 39. DOI: http://dx.doi.org/10.1016/j.econmod.2014.02.018

Nakamura, L.I., (2010). Intangible assets and national income accounting. Review of Income Wealth, 56(1). DOI: https://doi.org/10.1111/j.14754991.2010.00390.x

Pietrzak, M. (2010), Application of economic distance for the purposes of a spatial analysis of the unemployment rate for Poland, Oeconomia Copernicana, Vol. 1, pp. 79-98. DOI: http://dx.doi.org/10.12775/OeC.2010.005

Pike, A. (2009). Brand and branding geographies. Geography Compass, 3,(1). DOI: https://doi.org/10.1111/j.1749-8198.2008.00177.x

Pike, A. (2013). Economic geographies of brands and branding. Economic geography, 89(4). DOI: https://doi.org/10.1111/ecge.12017

Pike, A. (2015). Origination: The Geographies of Brands and Branding. John Wiley \& Sons.

Rogerson, P., (2001), A statistical method for the detection of geographic clustering, Geographical Analysis, 33. DOI: 10.1111/j.1538-4632.2001.tb00445.X

Suchecki, B., (2010). Modele regresji przestrzennej, B. Suchecki (red.), Ekonometria przestrzenna. Metody i modele analizy danych przestrzennych, Wydawnictwo C.H. Beck, Warszawa.

Suchecki, B., \& Olejnik, A., (2010). Miary i testy statystyczne w eksploracyjnej analizie danych przestrzennych, B. Suchecki (red.), Ekonometria przestrzenna. Metody i modele analizy danych przestrzennych, Wydawnictwo C.H. Beck, Warszawa.

Tobler, W., (1970). A computer model simulating urban growth in Detroit region, Economic Geography, 42(2).

Wang, S., Luo, K., Liu, Y., Zhang, S., Lin, X., Ni, R., ... \& Gao, X. (2015). Economic level and human longevity: spatial and temporal variations and correlation analysis of per capita GDP and longevity indicators in China. Archives of gerontology and geriatrics, 61(1). DOI: http://dx.doi.org/10.1016/j.archger.2015.03.004

Zéghal, D., \& Maaloul, A. (2011). The accounting treatment of intangibles-A critical review of the literature. Accounting Forum, 35(4), DOI: http://dx.doi.org/10.1016/j.accfor.2011.04.003 